\title{
'Abdīšóc of Gāzartā, Patriarch of the Chaldean Church as a Scribe
}

\author{
Anton Pritula* \\ Saint Petersburg, Russia \\ pritulanna@gmail.com
}

\begin{abstract}
'Abdī̌šc' of Gāzartā, the second patriarch (1555-1570) of the East Syriac Uniate (Chaldean) Church, is known as a founder of its literary tradition, and an author of numerous liturgical and non-liturgical poems. He was also active as a scribe, of whose production several manuscripts survive that were never studied before. The present paper discusses them, in particular the historical and autobiographical information that is found in the scribe's colophons and notes. This information is of a large importance for the history of the Christian communities in early Ottoman time.
\end{abstract}

\section{Keywords}

'Abdī̌šo of Gāzartā - Chaldean Church - Syriac poetry - manuscript production

\section{Introduction}

'Abdī̌šo' of Gāzartā, the second patriarch (1555-1570) of the East Syriac Uniate (Chaldean) Church, ${ }^{1}$ is known as a founder of its literary tradition, who composed numerous liturgical and non-liturgical poems, including descriptions of

* The author is grateful to Sebastian Brock, Amanda Gerber and Margherita Farina for their helpful corrections.

1 The dating of his death is disputable, and I follow the one established by Wilmshurst (D. Wilmshurst, The Eccesiastical Organisation of the Church of the East, 1318-1913, CsCo, Subsidia 104, Louvain, 2000, p. 94), and Murre-van den Berg (H.L. Murre-van den Berg, Scribes and Scriptures. The Church of the East in the Eastern Ottoman Provinces (1500-1850), Eastern Christian Studies 21, Leuven, 2015, pp. 250-251). 
the travels to Rome in a lengthy versified text. ${ }^{2}$ Although in the recent years his ecclesiastical and literary activities have drawn more attention of the scholars, most of his poetic legacy remains unpublished and greatly understudied. Many of his works contain information on his contemporaries and display important features of the cultural life of the East Syriac Church in the early Ottoman time. Presently, I am planning a series of articles on his verse texts. ${ }^{3}$ Even less attention has been drawn to the manuscripts he wrote. This paper in turn is to discuss his scribal production, and the additional information found in the copies he scribed. It is well-known that both poetry and the production of manuscripts reached their high point in early sixteenth century, having been united under the dominion of the Ottoman Empire. ${ }^{4}$ No less important is that scribal, owner's and reader's notes, both in verse and prose, became very popular as well. They contain extremely important information about the spiritual and cultural life of the Christian communities in that period, and about the manuscript circulation that accompanied them.

Seven manuscripts are testified to have been written by 'Abdiššc of Gāzartā (see Table 1), of which three are still extant (nos. 2, 4, 5), one was destroyed (no. 8 ), and the present location of the two is unknown (no. 1, 3).

2 It was published only in French translation, no original text has been edited so far. See J.M. Vosté, "Mar Iohannan Soulaqa, premier Patriarche des Chaldéens, martyr de l'union avec Rome ( $† 1555)$ ", Angelicum 8, 1931, pp. 187-234; see also A. Pritula, "'Abdī̌š̄ of Gazarta, the first Literate of the Chaldean Church: Poems dedicated to the popes of Rome", Вестник СанктПетербургского университета. Востоковедение и африканистика [Vestnik of Saint Petersburg State University], vol. 10, issue 3, pp. 374-391; <https://doi.org/10.21638/ spbu13.2018.307>.

3 One of them has just come out: Pritula, "Abdǐšō of Gazarta, the First Literate of the Chaldean Church: Poems Dedicated to the Popes of Rome", pp. 374-391; one more is to come out soon: idem, "East Syriac Literary Life in the mid-16th Century: 'Abdī̌sō' of Gāzartā and Older Contemporary Poets", Вестник Санкт-Петербургского университета. Востоковедение и африканистика [Vestnik of Saint Petersburg University. Oriental and African Studies], 1, 2019 (forthcoming).

4 For instance, see Murre-van den Berg, Scribes and Scriptures, p. 81. 
TABLE 1 Manuscripts written by 'Abdī̌sōó of Gāzartā

\begin{tabular}{|c|c|c|c|c|c|}
\hline $\begin{array}{l}\text { No. of } \\
\text { the MS }\end{array}$ & $\begin{array}{l}\text { HMML source } \\
\text { number/shelfmark }\end{array}$ & Present repository & $\begin{array}{l}\text { Date of } \\
\text { production }\end{array}$ & $\begin{array}{l}\text { Place of } \\
\text { production }\end{array}$ & Title of the text(s) \\
\hline 1 & $\begin{array}{l}\text { Vorlage of NDS } \\
\text { (Vosté) } 296^{\mathrm{a}}\end{array}$ & $\begin{array}{l}\text { Notre-Dame des } \\
\text { Semences }\end{array}$ & $155^{2}$ & Gāzartā & $\begin{array}{l}\text { Book of splendors by } \\
\text { Bar 'Ebrōyō with } \\
\text { explanation of } \\
\text { ambiguous words }\end{array}$ \\
\hline 2 & DCA $00065^{b}$ & $\begin{array}{l}\text { Chaldean } \\
\text { Archdiocese of } \\
\text { Alqosh }\end{array}$ & $155^{2}$ & $\begin{array}{l}\text { Mardin, } \\
\text { Monastery of } \\
\text { Saint Jacob (Mār } \\
\text { Ya'qūb) }\end{array}$ & $\begin{array}{l}\text { Metrical Grammar by } \\
\text { Bar 'Ebrōyō }\end{array}$ \\
\hline 3 & $\begin{array}{l}\text { Diyarbakir (Scher) } \\
130^{c}\end{array}$ & $\begin{array}{l}\text { Chaldean } \\
\text { Cathedral of } \\
\text { Mardin; formerly } \\
\text { in Diyarbakir; }\end{array}$ & 1554 & $\begin{array}{l}\text { Church of Mār } \\
\text { Pētiōn, Amid (?) }\end{array}$ & $\begin{array}{l}\text { Gospel of Mathew } \\
\text { (Arabic translation by } \\
\text { Ibn al-Tayyib) }\end{array}$ \\
\hline 4 & SMMJ $116^{\mathrm{d}}$ & $\begin{array}{l}\text { St. Mark } \\
\text { Monastery, } \\
\text { Jerusalem }\end{array}$ & 1554 & $\begin{array}{l}\text { Episcopal cell, } \\
\text { church of Mār } \\
\text { Pētiōn, Amid }\end{array}$ & $\begin{array}{l}\text { Rites of consecration } \\
\text { and ordination }\end{array}$ \\
\hline 5 & $\begin{array}{l}\text { Or. } 196 \text { (a folio } \\
\text { attached to a different } \\
\text { manuscript) }\end{array}$ & $\begin{array}{l}\text { Biblioteca } \\
\text { Medicea } \\
\text { Laurenziana, } \\
\text { Florence }\end{array}$ & $1562(?)$ & $\begin{array}{l}\text { Monastery of } \\
\text { Ya'qōb Hūb̄īhāyā } \\
\text { (the Recluse) near } \\
\text { Seert (?) }\end{array}$ & $\begin{array}{l}\text { Draft of a letter to } \\
\text { Pius IV }\end{array}$ \\
\hline 6 & SMMJ $159^{\mathrm{f}}$ & $\begin{array}{l}\text { St. Mark } \\
\text { Monastery, } \\
\text { Jerusalem }\end{array}$ & $\begin{array}{l}1566 \text { or } \\
1567\end{array}$ & $\begin{array}{l}\text { Monastery of } \\
\text { Ya'qōb Hẹbishāyā } \\
\text { (the Recluse) near } \\
\text { Seert }\end{array}$ & \\
\hline
\end{tabular}

a J.M. Vosté, Catalogue de la bibliothèque syro-chaldéenne du couvent de Notre-Dame des Semences près d'Alqoš (Iraq). Rome / Paris, 1929, p. 109.

b Available online; vHMML permanent link: <https://w3id.org/vhmml/readingRoom/ view/500565 >. Most likely, it is the one described in J. Habbi (ed.), Catalogue of the Syriac Manuscripts in Iraq, Publications of the Iraqi Academy, Syriac Corporation, Baghdad, 19771981 , p. 248 , cat. 65 .

c A. Scher, "Notice sur les manuscrits syriaques et arabes conservés à l'archevêché chaldéen de Diarbékir", Journal asiatique X, 10 (1907), pp. 413-414. Scribal note on fol. $1 \mathrm{r}$ also mentions that the manuscript was donated to the church of Mār Pētion by the priest 'Abdallah. The manuscript was not among those digitized by HMML team.

d F. Yu. Dolabani, and G. Yo. Ibrahim, Catalogue of the Syriac Manuscripts in St. Mark's Monastery (Dairo Dmor Marqos), Damascus, 1994, pp. 265-256.

e See M. Farina, "A New Autograph by 'Abdīšō' Marūn", Journal of Eastern Christian Studies 70 (3-4), 2018, pp. 241-256. 
TABLE 1 Manuscripts written by 'Abdī̌sōo of Gāzartā (cont.)

\begin{tabular}{|c|c|c|c|c|c|}
\hline $\begin{array}{l}\text { No. of } \\
\text { the MS }\end{array}$ & $\begin{array}{l}\text { HMML source } \\
\text { number/shelfmark }\end{array}$ & Present repository & $\begin{array}{l}\text { Date of } \\
\text { production }\end{array}$ & $\begin{array}{l}\text { Place of } \\
\text { production }\end{array}$ & Title of the text(s) \\
\hline 7 & Note in Vat. Syr. 184 & Vatican Library & $\begin{array}{l}1568, \\
\text { November }\end{array}$ & $\begin{array}{l}\text { Monastery of } \\
\text { Ya'qōb Ḥ̄b̄īshāyā } \\
\text { (the Recluse) near } \\
\text { Seert }\end{array}$ & \\
\hline 8 & Seert (Scher) $15^{g}$ & $\begin{array}{l}\text { Destroyed; } \\
\text { formerly in } \\
\text { Chaldean } \\
\text { Archdiocese of } \\
\text { Seert }\end{array}$ & $\begin{array}{l}1569 \\
\text { October } 20\end{array}$ & $\begin{array}{l}\text { Monastery of } \\
\text { Ya'qōb Ḥ̄b̄īshāyā } \\
\text { (the Recluse) near } \\
\text { Seert }\end{array}$ & $\begin{array}{l}\text { New Testament } \\
\text { (Syriac) }\end{array}$ \\
\hline
\end{tabular}

f See the description in Dolabani, Catalogue of the Syriac Manuscripts, pp. 339-344; Available online; vHMML permanent link: <https://w3id.org/vhmml/readingRoom/view/501291>.

$\mathrm{g}$ A. Scher, Catalogue des manuscrits syriaques et arabes, conservés dans la Bibliothèque épiscopale de Séert (Kurdistan) avec notes bibliographiques. Mosul: Imprimérie des pères dominicains, 1905, pp. 10-12.

One could assume that the number of the manuscripts produced by this hierarch and literateur might have been much larger than those extant today. Their repertoire is very broad, some containing New Testament (no. 3, 7) and liturgical texts (no. 4), while at least two of them contain works of Bar 'Ebrōyō (nos. 1, 2).

No less important is that the extant copies scribed by 'Abdīšóc of Gāzartā contain texts in both Syriac and Arabic (no. 6), which reflects the bilingual character of the East Syrian Church in the early modern period. There is exact evidence that at least one manuscript (no. 4) was owned and used by the scribe and patriarch himself, as follows from numerous notes and additions made in his hand, which are the subject of discussion in the current publication.

The earliest known manuscript scribed by 'Abdīšóc of Gāzartā (the Vorlage of no. 1; not listed in the table) dated $155^{2}$ is not available at present. The only evidence of it is found in the colophon of a late copy made in Alqosh that used the patriarch's autograph as a Vorlage. Even the present location of this copy itself is unknown due the recent events in Iraq. Although Wilmshurst mentions that the Vorlage of the NDS 296 was scribed by 'Abdǐšóc while he was a monk in the monastery of Mār Aḥhā near Gāzartā, referring to the record in the catalogue by Vosté. The latter in fact does not contain any indication of the place of production and only mentions its date.

Unfortunately, the library of Notre-Dame des Semences monastery in Alqosh was not digitized by the HMML team, and we can only judge about 
most of its manuscripts from the catalogue by Vosté. ${ }^{5}$ There is some chance though that this Vorlage mentioned there is in fact the present DCA 00065 (no. 2). First, it contains the same text; secondly, it is kept in another library of the same town (Alqosh); thirdly, the date the Vorlage is reported to have been completed is very similar to the dating of DCA 00065 ( $\left.155^{2} \mathrm{AD}\right)$.

A very important document was recently discovered and published by Margherita Farina (no. 5). ${ }^{6}$ It is a text apparently representing a draft of the letter by 'Abdǐš̄', already a patriarch of the East Syriac Catholic Church, that he sent to pope Pius IV in $1562 ; 7^{7}$ it contains the famous list of the dioceses of the East Syriac Church over which he claimed his supremacy. ${ }^{8}$ This leaflet attached to manuscript Or. 196, now in Biblioteca Medicea Laurenziana of Florence, was most likely written by the hierarch himself, being thus his autograph, unlike the final official version of this document in Vat. Syr. 99 written in West Syriac script. In the introductory paragraph, 'Abdī̌š ${ }^{\complement}$ mentions that he originated from the city Gāzartā and started his Church career as a monk in the monastery of Mār Aḥ̣āa and Mār Yōḥannān in its neighborhood. ${ }^{9}$ This important biographic information fits very well the data from the colophon of the Vorlage of Alqosh NDS 296 reported by Vosté. ${ }^{10}$

The last three manuscripts scribed by 'Abdīšō' of Gāzartā (apart from draft attached to Or. 196) ${ }^{11}$ were produced by him at the Monastery of Ya'qōb Ḥbī̌šayā (the Recluse) near Seert, his new residence, while already being a patriarch (nos. 5, 6, 7). The non-extant Seert 15 (no. 8), probably destroyed with the rest of this collection in 1915, contained a detailed scribal note by 'Abdīšs $\bar{c}^{c}$ describing his method of using vocalization based on the copies available to

5 Vosté, Catalogue de la bibliothèque syro-chaldéenne du couvent de Notre-Dame des Semences, p. 109.

6 Farina, "A New Autograph", pp. 241-256.

$7 \quad$ The final version of this text is known in the Latin translation published by S. Giamil in 2002 (see S. Giamil, Genuinae relationes inter sedem Apostolicam et Assyriorum Orientalium seu Chaldaeorum ecclesiam nunc majori ex parte primum editae historicisque adnotationibus illustratae. Rome, 1902, pp. 61-66).

8 The document directly refers to the Trent Council which 'Abdī̌̌óc was not able to attend; thus, the epistle has a precise dating (see Farina, "A New Autograph", pp. 247, 249). For the numerous confessions of faith made by him and his predecessor Yōḥannān Sūlāqā in Rome see H.G.B. Teule, "Les professions de foi de Jean Sullāqā, premier patriarche chaldéen, et de son successeur 'Abdisho' d-Gāzartā", L'union à l'épreuve du formulaire. Professsions de foi entre églises d'orient et d'occident (XIIIe-XVIIIe siècle), ed. M.-H. Blanchet and F. Gabriel, Leuven-Paris-Bristol, 2016, pp. 259-269.

9 Ibid., pp. 245-247.

10 Vosté, Catalogue de la bibliothèque syro-chaldéenne du couvent de Notre-Dame des Semences, p. 109; see also Pritula, "East Syriac Literary Life in the mid-16th Century".

11 See Farina, "A New Autograph", pp. 242-254. 
him. It also mentions that it was written for Mār Ya'qōb, the supervisor of the Ya'qōb Ḥbīshāyā monastery, the residence of the patriarch and scribe himself. ${ }^{12}$ One more manuscript, SMMJ 159, was scribed by 'Abdiššc for the same person in 1566 or 1567 (no. 6; see Appendix 2).

\section{Manuscript SMMJ 00116 Written by 'Abdī̌šc' Gāzartā, and the Biographic Information It Contains}

One of 'Abdīšō's autographs belongs to the library of the West Syriac (Syriac Orthodox) monastery of Saint Mark in Jerusalem (source number SMMJ 00116; see Table 1, no. 4). It is one of the manuscripts donated by East Syriac pilgrims to the chapel of the Virgin Mary in Jerusalem that belonged to their Church. After their donation, most of these manuscripts entered the library of the Orthodox Patriarch of Jerusalem. This manuscript is one of three that reside in the Saint Mark Monastery. ${ }^{13}$

It has a detailed colophon stating that it was scribed by 'Abdīšō', bishop of Gāzartā in Amid (Diyarbakir). As pointed out by Heleen Murre-van den Berg, colophons of East Syriac manuscripts become an almost obligatory component in this period; they were constructed according to certain rules and usually bear significant information. ${ }^{14}$ I quote only a relevant passage from this colophon, since its entire text takes several folios, as is usual for this tradition:

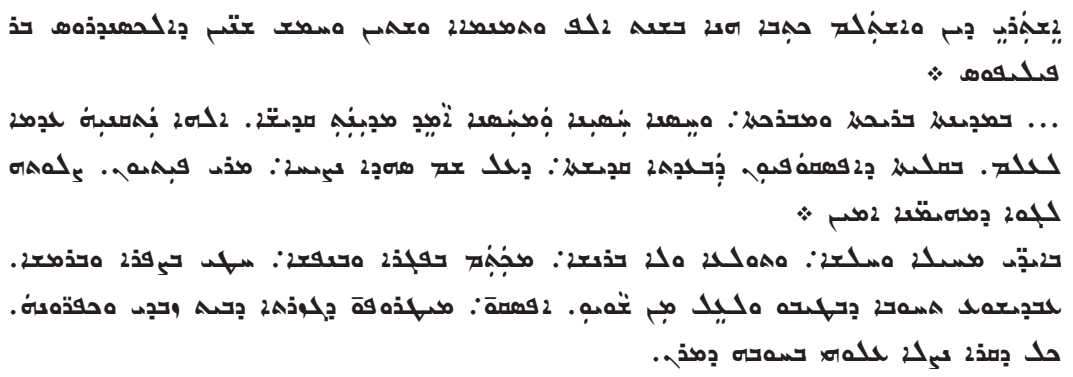

This book was started and finished in year one thousand eight hundred sixty five of the era of Alexander, son of Philip ... in the blessed and blissful, strong and strengthened city of Amid, the city of the saints (let God

\footnotetext{
12 Scher, Catalogue des manuscrits syriaques et arabes, conservés dans la Bibliothèque épiscopale de Séert, pp. 11-12.

13 Dolabani, Catalogue of the Syriac Manuscripts in St. Mark's Monastery, pp. 264-267, 339344, 380-381.

14 Murre-van den Berg, Scribes and Scriptures, pp. 113-143.
} 
protect it forever and ever) in the episcopal cell of the church dedicated to the glorious martyr lord Pētiōn ([let] his prayer for the believers be permanent) by the hand of the weak and unable - a worm, but not a man, unclean in soul and body, committing sins in the morning and in the evening, - 'Abdǐšō', by the Grace surpassing his deserts Bishop and Metropolitan of Gāzartā of Beth Zabdai and its villages. Let everyone who reads (this) pray for him out of the love of our Lord (SMMJ 00116, fol. 113v).

The colophon provides a conventional Syriac dating system to specify the era, a system connected to the foundation of the Seleucid state in 311, but usually referred to as the one of Alexander the Great. The dating of this manuscript thus corresponds to $1554 \mathrm{CE}$, a year, when 'Abdǐšóc was already ordained as the bishop of Gāzartā, but a year before his patriarchate. It is important that although his title connected him to this city, he was residing in Amid (Diyarbakir) until his patriarchal post was confirmed in Rome, when he moved his main residence to the monastery of Jacob the Recluse, near Seert. At the time, Gāzartā recognized the traditional line of the East Syriac Church (based in Rabban Hōrmizd monastery near Alqosh) and did not support the Uniate Patriarchate. For this reason, 'Abdīšō's seat was apparently based in Amid (Diyarbakir), which was also the center of the entire Uniate Church in its first years and the residence of its first patriarch, Yōhannān Sūlāqā. ${ }^{15}$ This suggestion is confirmed by another of 'Abdī̌so's manuscripts written in this city in 1554, according to Wilmshurst's analysis of the existing manuscript collections. ${ }^{16}$

This new colophon establishes that his 'bishop's cell' was located in the Church of Pētiōn, which may have played a significant role in the early period of the first Chaldean Church history. Several extant manuscripts were either commissioned by this church or donated to it. Additionally, it obtained a considerable donation of lands in a nearby village during the early seventeenth century. ${ }^{17}$ In 1615 , numerous priestly stoles and crowns were brought to this Church from Rome to be distributed between parishes. It is also important that deacon Gīwargiss, who initiated the donation of the lands to this church in 1603, also sponsored traditional gifts for the East Syrian Church in Jerusalem dedicated to Virgin Mary. ${ }^{18}$ Such contacts might explain why this manuscript

\footnotetext{
15 Wilmshurst, The Eccesiastical Organisation, p. 55.

16 Ibid., p. 55.

17 Wilmshurst, The Eccesiastical Organisation, p. 55-56.

18 Ibid., p. 56.
} 
moved from Amid to Jerusalem. The activities of the East Syrian pilgrims in Jerusalem were studied in an article by Sebastian Brock. ${ }^{19}$

The same manuscript has a second colophon, written by the same person in the same hand, but already after he became a patriarch in 1555 (see Appendix 1). Unlike the first one, it is in verse and refers to 'Abdīšō' in the first person, but already mentions his new Church position.

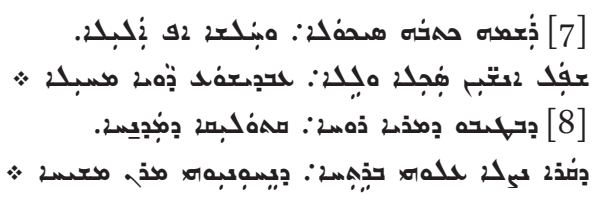

[7] It was copied and written by the puny, limp and sickly, lowest of all people, foolish and fatuous, weak and feeble 'Abdīšō', [8] who is Catholicos of the East by the grace of the Lord Spirit.

May a reader pray for him with fervour, so that our Lord Christ may rescue him (sMmJ oo116, fol. 114v).

He might have added the poetic colophon to register his new authority, which was, obviously, a most important task of a colophon at this time. Furthermore, the colophon offered a poetical exercise for this author, being an almost literal rendering of the previous prose colophon. It is worth mentioning that poetical colophons became an important part of the Syriac manuscript tradition during this period.

From this colophon, it becomes clear that 'Abdīšō owned the manuscript for several years. Since the manuscript contains rites of consecration and ordination, one can suppose that the hierarch scribed it for his Church needs, as was common at the time, and used it at least while ordaining new priests and creating the new Church's infrastructure. Vestiges of this long and intensive use appear as dozens of poems written in the same hand by the same person. They were never studied and still need a careful research. Some of these previously undiscovered poems can be considered a kind of poetic exercise, containing rhymes on certain names and historical epigrams for contemporary

19 S.P. Brock, "East Syriac Pilgrims to Jerusalem in the Early Ottoman Period", ARAM 18-19 (2006-2007), pp. 189-201. 
historical figures. Besides, there are numerous notes in 'Abdī̌šo's hand, some of them are very informative. ${ }^{20}$

\section{Manuscript DCA 00065 of Metrical Grammar Written by 'Abdīšóc of Gāzartā}

One more manuscript scribed by 'Abdī̌šc of Gāzartā is now kept in the collection of Chaldean Diocese of Alqosh (see Table 1, no. 2), which is certainly a different one than the famous library of the Catholic monastery of Virgin Mary (Notre Dame des Semences) located near this town. ${ }^{21}$ The former that consists of around manuscripts was digitized by the HMML team, whereas the latter is still not available online, and the scholars have only old microfilms of selected manuscripts at their disposal. ${ }^{22}$

This manuscript contains Bar 'Ebrōyō's Metrical Grammar alongside other poems and treatises, and was copied by 'Abdǐšo' for himself. The colophons identify the circumstances of its scribing (DCA 00065, fol. 113r-113v). For example, 'Abdīššc notes that he copied the text in $155^{2}$ in Mardin, while he was a bishop of Gāzartā (fol. 113r-113v), not in Diyarbakir as was the case when he was copying his other manuscripts before becoming a Patriarch (see Table 1, nos. 3 , 4).

The colophon follows a complex structure, a sequence of certain sections or information blocks, common for East Syriac manuscripts of this period, recently analyzed by Heleen Murre-van den Berg. ${ }^{23}$ The first section normally mentions the exact date of finishing the work, which is also the case in this manuscript:

\footnotetext{
20 I am planning to write a special paper discussing these short texts.

21 See Vosté, Catalogue de la bibliothèque syro-chaldéenne du couvent de Notre-Dame des Semences.

22 On this text and the features of its copies see M. Farina, "La Grammatica Metrica di Barhebraeus (XIII sec.) e le sue glosse. Siriaco, greco e arabo in contatto", Rappresentazioni linguistiche dell'identità. Edited by Benedetti, Marina. Quaderni di AI $\Omega$ N, N.S. 3. Napoli: Università degli Studi di Napoli "L'Orientale", 2015, pp. 107-125; M. Farina, "Barhebraeus' Metrical Grammar and Ms. BML Or. 298: Codicological and Linguistic Remarks", Studi classici e orientali 62 (2016), pp. 345-36o; M. Farina, "The Syro-Arabic Glosses to Barhebraeus' Metrical Grammar", in Language and Identity in Multilingual Mediterranean Settings: Challenges for Historical Sociolinguistics. Edited by Molinelli, Piera. Trends in Linguistics. Studies and Monographs 310. Berlin / New York, 2017, pp. 157-170.

Murre-van den Berg, Scribes and Scriptures, pp. 113-143.
} 
... on 18th day of the blessed month Ab, on Thursday, in the year 1863 of the Greek era, and following blessed Arabs, in year nine hundred fifty nine ... (fol. 113r).

The latter corresponds to 18 August $155^{2} \mathrm{AD}$.

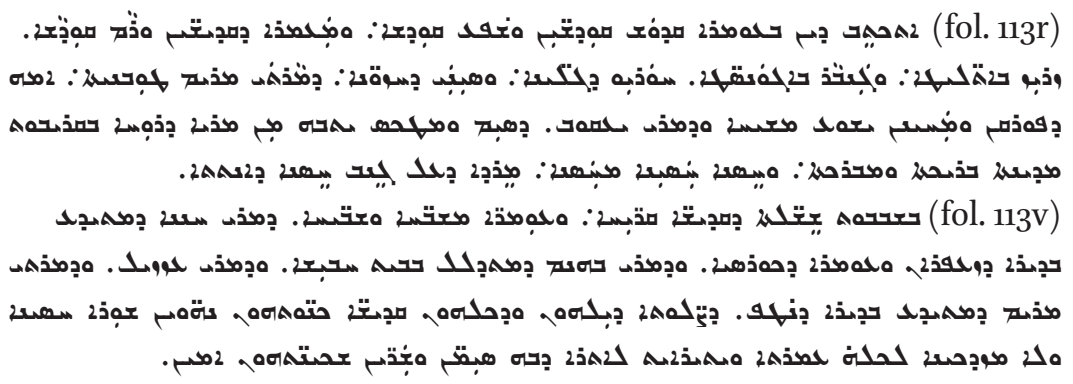

(fol. 113r) It was written in an utmost holy cloister, abundant in holiness, and an abode of the saints and high in holiness, strong with the combatants, and mighty with fighters, Horeb of revelations, and Sinai of visions, of blessed Mārt Maryam, mother of our Savior, and redeemer Jesus Christ, and of Mār Ya'qōb that is settled and founded by the Lord Spirit near blessed and blissful city of Mardin, close of the (village) Hesnā d-anttā (Fortress of the Lady), (fol. 113v) in the neighbourhood of a series of the outstanding saints, and the glorious and glorified cloisters of Hannānyā, known as Dayr Za'farān, and the cloister of the See, and of Mār Behnam designated as House of the Recluse, and of Mār 'Azazēl, and of Mārt Maryam, known as the monastery 'of the drop of water', and may their prayers, and of all the saints alike them, be a solid and invincible wall for all the universe, and most of all, in the land, where their resting-places are laid and settled.

Mardin is well-known for its dominant West Syriac (Syrian Orthodox) community and its monasteries and churches. The most important monastery was Mōr Ḥanōnyō (Mār Ḥannānyā), better known as Dayr al-Za'farān mentioned in the colophon, where the residence of maphrians of the East (the Syrian Orthodox Metropolitan in charge of the diocese to the East of the Euphrates) was also placed at that time. The monastery mentioned by 'Abdīšō' as a place of 
production of the manuscript might be the Syriac Orthodox one of Saint Jacob (East Syriac: Mār Ya'qōb; West Syriac: Mōr Ya'qūb), near Mardin. ${ }^{24}$ Thus, the colophon demonstrates close contacts between the East and West Syriac Churches in producing manuscripts. The copyist was staying in a Syriac Orthodox monastery and cooperating with West Syriac monks, as will be demonstrated below.

That might be the reason why 'Abdī̌ōo's colophon recognizes the hierarchs of the West Syrian Church as the only Church authority. He hereby demonstrates that, as a scribe and bishop of the East Syriac Chaldean Church, he considered this city to be another Church tradition's jurisdiction:

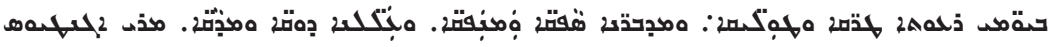

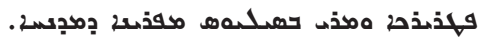

... in the days of skilled and superior shepherds, proficient and learned administrators, thoughtful and competent hierarchs Mār Ignatius the Patriarch and Basilius, Maphrian of the East (fol. 113v).

The manuscript being discussed was written at the time of West Syrian Church Patriarch Ignatius 'Abdallah I (1520-1557), who might be the hierarch meant in the colophon. This person is reported to have moved the patriarchal residence from Dayr al-Za'farān to Amid (Diyarbakir), and is known as one of the initiators of Syriac Church printing. ${ }^{25}$

In fact, the same colophon mentions the famous Dayr al-Zacfarān and several smaller cloisters of this Church. He even lists the monks who helped him copy the manuscript, expressing his gratitude to assistants in particular to the one named Ni'ma(h):

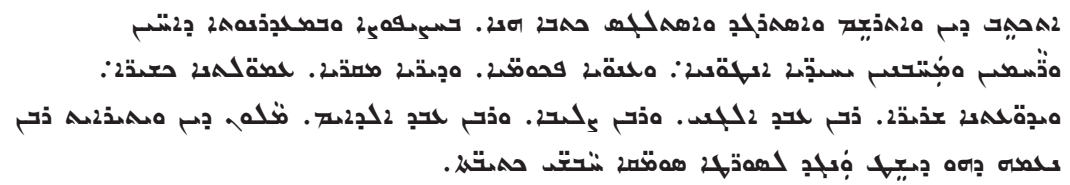

24 Wilmshurst, The Eccesiastical Organisation, p. 78; this monastery was still functioning in the eighteenth century; see G. Kiraz, "Shem'un II, Basileios", in: Gorgias Encyclopedic Dictionary of the Syriac Heritage, ed. S.P. Brock, A.M. Butts, G. Kiraz, and L. van Rompay, Piscataway, NJ, 2011, p. 375.

Kiraz, "'Abdullah I bar Stephanos", p. 4. 
This book was scribed, drawn and copied by an effort and help of our brothers and our dear friends, Antonian hermits, and Pachomian cenobites, and choice monks and diligent workers, and true scholars Rabban 'Abd al-Ḡanī, and Rabban Șlībā, and Rabban 'Abd al-Dāim, and most of all, our lord Ni'mah [or: Na'amah], who drew out red lines that enclose the script (DCA 00065, fol. 113v).

The last name mentioned in the colophon is very likely to be an abbreviation for Ni'matallah, which is a usual practice in the Near East. The way it is written in the colophon, with the final $h$, is a usual way of rendering the Arabic Ta marbüta (̈)), which was usually not pronounced, in the Garshuni texts. The reference apparently pertains to the famous West Syrian scholar and literateur of the same name, who was initiated as a monk in the Dayr al-Za'farān in 1535, meaning that he might have lived there at the time of 'Abdǐšo's visit to Mardin. It is even known that the short form of the name, Ni'ma [or: $\mathrm{Na}^{\prime} \mathrm{ama}$ ], was attested for him. ${ }^{26}$

In Mardin, one of the most important cultural centers of West Syriac tradition, Ni'matallah studied history, logic, astronomy, medicine and the art of drawing. In 1555, he was ordained as a maphrian, and in two more years as Patriarch Ignatius of the Syrian Orthodox (West Syriac) Church, after the death of 'Abdallah I. Despite his numerous important positions, his unique fate gained him renown. After Ignatius Ni'matallah established contacts with the Roman Church, the Ottoman authorities forced him to resign and convert to Islam under threat of death in 1576 . He eventually fled to Rome, returned to Christianity, and participated in the Pope's committee on the calendar reform. Contributing to this calendar, Ni'matallah made the works of the famous Arabic astronomers available to this committee. One year after introducing the Gregorian calendar to Catholic countries, he died. ${ }^{27}$

By naming this famous hierarch and scholar, this colophon offers a unique case of collaboration between two future patriarchs from two different Churches to create one manuscript. The colophon specifies that the West Syrian monk's supplied the red-ink lines that frame the text. Framing the text field (not the miniatures or colophons) in Syriac manuscripts was not as wide spread as in Persian and Arabic ones. It is met rather rarely, usually in cases,

26 See Murre-van den Berg, Scribes and Scriptures, p. 54.

27 See G. Kiraz, " Ni'matullah, Ignatius", Gorgias Encyclopedic Dictionary of the Syriac Heritage, Ed. S.P. Brock, A.M. Butts, G. Kiraz, and L. van Rompay, Piscataway, NJ, 2011, p. 308. 
when a manuscript has more than one column. ${ }^{28}$ It is very likely that the copyist was not skilled in this operation, especially given that the manuscripts of Bar 'Ebrōyō's the Metrical Grammar request a specific layout: two uneven columns for the main text and for the commentary. This way of framing might have been much more familiar to the Ni'matallah, the West Syriac scientist, draftsman and a Church man.

Since a few other names are mentioned as the assistants, one may expect that some elements of the manuscript decoration were produced by them, for instance, the calligraphy that forms the decorative borders, and the paintings that were filling them. The "brothers" could not have contributed to the rubrics because they were made in East Syriac script resembling the handwriting throughout the text. Additionally, 'Abdǐšo's other manuscripts demonstrate that he tends to write the rubrics himself (see Table 1, nos. 3, 4, 5). Unlike them, the calligraphy in the decorative borders is written in Estrangela handwriting, an archaic style dating to the earlier stage of Syriac script, yet still a calligraphic style used in both Churches for decoration and titling.

The style of decorative borders in turn resembles very much that of the West Syriac manuscripts, both in its colours and guilloche ornament. ${ }^{29}$ In any case, the colophon's list of monastic contributors reveal that the manuscript was a product of extensive collaboration between two Church traditions.

A note in 'Abdī̌šo's hand was made below the lower margin of the text field of the colophon:

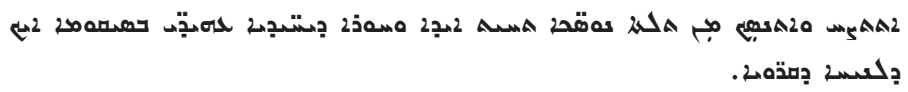

It was scribed and copied from three manuscripts under supervision and watch of the monks mentioned in the colophon for the convenience of readers (DCA 00065, fol. 113r).

As follows from this note, the copyist was producing a kind of "critical" (or at least, an authorized) edition of Bar 'Ebrōyō's Metrical grammar, for which he used a few Vorlagen that were extant in Mardin, and he even consulted some monks, evidently West Syrian. Thus using the manuscript library and the help

28 See W.H.P. Hatch, An Album of Dated Syriac Manuscripts, Monumenta Palaeographica Vetera, 2nd series, Boston, 1946, pp. 15-16. The operation is rather referred to as "ruling columns in ink".

29 See for instance DCA 00065, fol. 68v, 78v, 82r, 83r, 84r, 85v, 88r, 89r, 9ov, 91v, 92v, 97v, 101v, 102v, , 104r, 104V, 108v, 109v. 
of the local educated elite might have been the main reason for 'Abdǐšós visit to this city and his working in Saint Jacob monastery of the Syriac Orthodox Church. Moreover, his contacts with the hierarchs of this Church that might have had a rather constant and intensive character are reflected also in two odes composed by him, one dedicated to a hierarch, apparently a maphrian (CCM 00398, fol. 248r-248v), and another one, to a "maphrian, who has become patriarch" (ССм 00398, fol. 248v-149r); both were never published and survive only in ССм 00398. Both have acrostics with the name of addressee, the first one - Basilius, and the second one - Ignatius, both hardly giving anything for the persons' identification, each of them being a standard part of an official name of anyone who had a corresponding Church position. ${ }^{30}$

Such literary contacts and textual transmissions between two Syriac traditions are evinced by more than this manuscript. Such contacts occurred for centuries, indicating that their shared roots were never entirely severed. The link between them became stronger during the Syriac Renaissance, when both Churches' hierarchs participated in the Mongol dynasty's court ceremonies. For example, Grīgōrīūs bar 'Ebrōyō and Khāmīs bar Qardāḥē, two outstanding literateurs from both Churches, conducted a correspondence in poetry. ${ }^{31}$ The latter, probably slightly younger, even dedicated at least two odes to his WestSyriac contemporary, odes that were recently studied and published by myself. These odes demonstrate that literary and personal contacts between the two Churches also existed in the sixteenth century, when multi-denominational literary circles became a standard model for the Syriac Renaissance. Writers from both Church traditions used this pattern to create historical parallels to contemporaneous events. The resulting poems especially focused on the movement to unify with the Roman Church, intensifying inter-Church contacts between most Eastern Churches during the sixteenth century.

30 Gorgias Encyclopedic Dictionary of the Syriac Heritage, ed. S.P. Brock, A.M. Butts, G. Kiraz, and L. van Rompay, Piscataway, NJ, 2011, pp. 488-490.

31 For instance, see A. Pritula, ,Zwei Gedichte des Hāmīs bar Qardāhẹe: Ein Hochgesang zu Ehren von Bar 'Ebrōyō und ein Wein-Gedicht für die Khan-Residenz." Geschichte, Theologie und Kultur des syrischen Christentums: Beiträge zum 7. Deutschen Syrologie-Symposium in Göttingen, Dezember 2011, ed. M. Tamcke, and S. Grebenstein, Göttinger Orientforschungen, I. Reihe: Syriaca 46, Wiesbaden, 2014, pp. 315-328; A. Pritula, “One More Unknown Khāmīs' Ode in Honor of Bar 'Ebrōyō", Khristianskii Vostok, 8 (xIV), (2017), pp. 187-195. 
The above mentioned manuscript written by 'Abdǐšō was apparently used as a Vorlage for another copy of the Metrical Grammar by Bar 'Ebrōyō, presently in the Chaldean collection of Mardin (СCM 00024). ${ }^{32}$ A section of the colophon mentions that this manuscript was written "in the blessed and blissful Gāzartā of Bēt Zabdai" (CCM 00024, fol.10r) in Summer of 1866 AG/1555 CE (CCM 00024, fol. 9v). Besides, colophon reads:

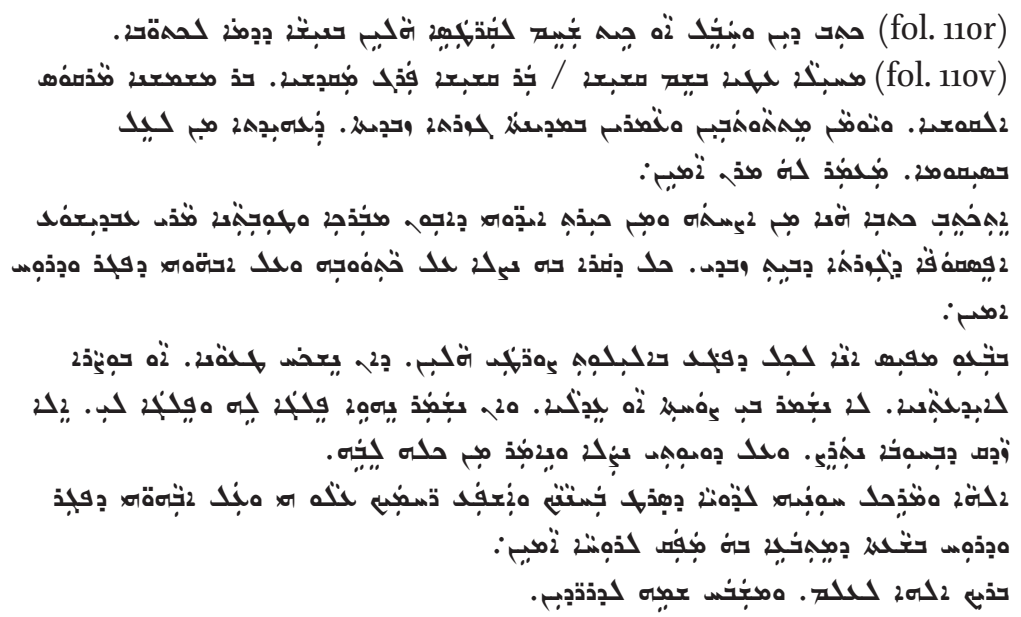

(fol. 110r) The feeble one, wrote, spoiled, i.e. soiled the paper - in a way that is usual for scribes - the priest, 'Atạyā by name, (fol. 110v) son of the priest Faraj, the pilgrim, ${ }^{33}$ son of the deacon Marqōs of Alqosh; and now they have got settled and live in the city of Gāzartā of Bēt Zabdai.

This book was written from a manuscript and a copy produced by our blessed and blissful father Mār 'Abdī̌šco', bishop of Gāzartā in Bēt Zabdai. Everyone, who will read it, may pray for its scribe and about his physical and spiritual fathers, amen.

I insistently entreat everyone who comes across the weakness of these my letters, if he finds an error of an unintentional imperfection, that he

32 Available at vHMML site; permanent link: <https://w3id.org/vhmml/readingRoom/view/ 132226>. See also Pritula, "East Syriac Literary Life in the Mid-sixteenth Century".

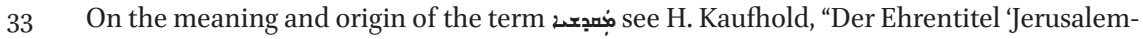
pilger' (syrisch maqdšāyā, arabisch maqdisī, armenisch mahtesi)”, Oriens Christianus, 75 (1991), pp. 44-61. 
does not address an abuse and put blame on me - and if he does, a part of it would fall on him and a part on me; but it is appropriate that he corrects it with love and prays about my weakness, and would say from his entire heart:

"God, Lord of everything, forgive by your clemency the one who scribed [it], and pour out your love on him and his physical and spiritual fathers in the hour, when response is required, amen!"

Blessed is God forever, and glorious is His name for eternity! (fol. 11or$110 v)$

Thus, the copy was made a year after the Vorlage by 'Abdīšō' was completed. The copyist 'Ațāyā of Alqosh, worked mostly in the city of Gāzartā, and is probably the most well-known East Syriac scribe of the early modern period. Twenty-five manuscripts of his production have survived in the chronological range between 1536 and $1594 .{ }^{34}$ Apparently, this manuscript was copied, while 'Abdīšō' was staying in this city, when he might have delivered his autograph for copying. It is not known for sure, who commissioned this copy and which patriarchal line he adhered to. 'Ațāyā himself is known as a priest of the traditional East Syriac (Rabban Hōrmīzd) line, which makes his mentioning of the Chaldean bishop 'Abdī̌šc rather unusual and also requiring some explanations. This name appeared in the part of the colophon in connection with the manuscript's pedigree - a reference to a Vorlage of the present copy, as it is very common for late East Syriac manuscript colophons. Granted, the owner and the scribe of the Vorlage is mentioned with his Church title as bishop of Gāzartā, which might have been in fact also a part of his name. If 'Abdī̌š̄' originated from the same city, that could explain such close contacts between the two literates from the two rival lines. ${ }^{35}$

As Murre-van den Berg has shown, the colophons of that period has a certain structure containing an obligatory (or almost obligatory) set of propositions, ${ }^{36}$ where mentioning a Vorlage and its scribe or owner may be important for the designation of the text authority. Thus, referring to the name of 'Abdīšóc is meant here not as a Church authority to which the scribe belongs, but rather as a reference to the reliability of the manuscript's text. And it is very likely that this literateur was well-known in this area as a writer and scribe, which might have increased the value of 'Ațāyā's copy. ${ }^{37}$

34 Hilmshurst, The Eccesiastical Organisation, pp. 114, 400-423.

35 More detailed, I discuss the relations of these two poets and scribes, as well as the origin of 'Abdīšō' in Pritula, "East Syriac Literary Life in the Mid-sixteenth Century".

36 Murre-van den Berg, Scribes and Scriptures, pp. 113-143.

37 Moreover, the two manuscripts under discussion became a text authority for later copies of the text. Thus, a manuscript of the Metrical Grammar written in 1723 (now, in Tehran, 
In the section of the colophon mentioning the Church authorities, 'Atạyā refers to the Rabban Hōrmizd monastery line of the East Syriac Church and its hierarchs, such as traditional Patriarch Šem'ōn (apparently, Šem'ōn viI, 15391558) and Yawsep, bishop of Manșūia and Gāzartā (ca. 1555-ca. 1558$)^{38}$ with appropriate honorific epithets (fol. 110r). It is well-known that the copyist of this manuscript was an adherent of the traditionalist patriarch line - as well as the city of Gāzartā itself at that period. So his mentioning this line in the relevant part of the colophon is quite natural, while the mention of 'Abdišs̄', the Uniate bishop of Gāzartā, refers to the aspect of the manuscript's textual authority.

Nevertheless, similar or even more complicated cases of referring to two parallel East Syriac Churches' hierarchies in one manuscript are already known in the East Syriac tradition of this period. Thus, Brock collected a few such examples in his article on the East Syriac manuscripts donated to the East Syrian church of Mārt Maryam in Jerusalem. Most of them were scribed in the sixteenth-seventeenth century and mention either two patriarchs of both the Qudshanis and Rabban Hōrmīzd lines or a patriarch of the one line and a bishop representing the other one at the same time. ${ }^{39}$ Such cases apparently need a more detailed study, first of all, to register the exact place of all such references in the colophons. Some of them might belong to the paragraphs referring to commissioners, donors, or scribes of a Vorlage, i.e. in any functions, others than direct Church authority. On the other hand, the above-mentioned cases certainly demonstrate an extremely complex ecclesiastic situation in this period of the East Syriac Church history.

One should also question, what the "manuscript authority" in that period meant. As pointed out by Murre-van den Berg, it became an important component in the text transmission, stating its correctness and reliability. ${ }^{40}$

The framing used in the copy written by 'Ațāyā is much less careful and strait that that of its Vorlage, to which a few West Syrian monks might have contributed. Apparently, such a type of frame used for the Metrical Grammar by Bar 'Ebrōyō was not quite usual for an East Syriac scribe. The rubric is written in Estrangela, in large letters very similar in shape to those in the Vorlage by 'Abdīšóc. The colour of the letters in this case are in alternating red and gold ink, which is common for East Syriac manuscript production. The space

source number TEH SJ 00001) mentions them both in the colophon (fol. 257rv) as its Vorlage; available at vHMML site; permanent link: https:/w3id.org/vhmml/readingRoom/ view/501321.

38 Hilmshurst, The Eccesiastical Organisation, pp. 102, 103, 117, 351, 823.

39 Brock, "East Syriac Pilgrims to Jerusalem", p. 197.

40 Murre-van den Berg, Scribes and Scriptures, pp. 113-143. 
around the headings is not filled with paint, but rather left blank, unlike that of the Vorlage. All the decorative elements are worked in red and black ink, in contrast to the Vorlage whose decoration is in typical East Syriac tradition. Thus, the design of 'Ațāyā's copy partially imitates the West Syriac tradition, but in most aspects the copyist follows the East Syriac one, to which he belonged. It is quite intriguing that the most famous manuscript produced by this scribe, the Gospel lectionary now in the Vatican library (Borg. Syr. 169) has a very elegant framing and extremely high quality design. This Evangelion was completed in Jerusalem in $1576 .{ }^{41}$ One may question whether these elements of the decoration were completed by the scribe in person, or by more decorators, possibly West Syriac ones, contributing to it. Both are quite possible: the chronological distance between the two copies produced by 'Ațāyā is 21 years, during which his scribal and decorative skills could significantly develop. On the other hand, in Jerusalem, a traditional center of West Syriac Christianity, an active collaboration with the adepts of this tradition is very likely.

It is also interesting that not just the contents of the Vorlage itself, but even the short poems preceding the main text were copied by 'Ațāyā, so that the general layout has been taken over from the source text. ${ }^{42}$ The contents and attribution of these verses I hope to examine elsewhere. At the same time, short poems present on front and rear flyleaves of the Vorlage written by 'Abdī̌šo' (see Table 2, nos. 1-4, 17-27) are absent from the copy by 'Ațāyā. This may mean that these small texts were written after the latter had made it: some of them by 'Abdīšō' thereafter, and some in a different hand, which might be a latter addition.

TABLE 2 Contents of DCA 00065 and CCM 00024 containing Metrical Grammar by Bar 'Ebrōyō, and other texts ${ }^{43}$

\begin{tabular}{|c|c|c|c|c|}
\hline \multicolumn{3}{|c|}{$\begin{array}{l}\text { Number The Text Title } \\
\text { of the text }\end{array}$} & \multirow{2}{*}{$\begin{array}{l}\text { Foliation in } \\
\text { DCA ooo65 }\end{array}$} & \multirow{2}{*}{$\begin{array}{l}\text { Foliation in } \\
\text { CCM } 00024\end{array}$} \\
\hline 1 & & Quatrain on testing ink (in the scribe's hand) & & \\
\hline 2 & & $\begin{array}{l}\text { Two quatrains on studying grammar (in the } \\
\text { scribe's hand) }\end{array}$ & $3 v$ & - \\
\hline 41 & \multirow{3}{*}{\multicolumn{4}{|c|}{$\begin{array}{l}\text { See J. Leroy, Les manuscrits syriaques à peintures conservés dans les bibliothèques d'Europe } \\
\text { et d'Orient. Contribution à l'étude de l'iconographie des églises de langue syriaque, Paris, } \\
1964, \mathrm{pp} .404-408 . \\
\text { For instance, cf. DCA } 00065 \text { (fol. } 5 \mathrm{v} \text { ) and cCM } 00024 \text { (fol. } 2 \mathrm{r} \text { ). } \\
\text { The notes on the flyleaves are not mentioned. For more details see Pritula, "Abdīšóc of } \\
\text { Gazarta, the first Literate of the Chaldean Church: Poems Dedicated to the Popes of } \\
\text { Rome". }\end{array}$}} \\
\hline 42 & & & & \\
\hline 43 & & & & \\
\hline
\end{tabular}


TABLE 2 Contents of DCA 00065 and CCM 00024 containing Metrical Grammar (cont.)

\begin{tabular}{lll}
\hline $\begin{array}{l}\text { Number } \\
\text { of the text }\end{array}$ & Foliation in & Foliation in \\
DCA ooo65 & CCM ooo2
\end{tabular}

\begin{tabular}{|c|c|c|c|}
\hline 3 & Quatrain on books (in the scribe's hand) & $4 \mathrm{r}$ & - \\
\hline 4 & $\begin{array}{l}\text { Title page of Metrical grammar by Bar 'Ebrōyō (in } \\
\text { the scribe's hand) }\end{array}$ & $4 \mathrm{~V}$ & - \\
\hline 5 & $\begin{array}{l}\text { Six short poems on grammar (in the scribe's } \\
\text { hand) }\end{array}$ & $5^{r}$ & $3 v-4 r$ \\
\hline 6 & Four short poems on grammar & $5 \mathrm{v}$ & $2 \mathrm{r}$ \\
\hline 8 & Notes on grammar (in the scribe's hand) & $6 r-7 r$ & $2 v-3 r$ \\
\hline 9 & Metrical grammar by Bar 'Ebrōyō & $7 \mathrm{~V}-112 \mathrm{~V}$ & $4 V^{-}$ \\
\hline 10 & Colophon (in the scribe's hand) & $112 \mathrm{~V}-114 \mathrm{r}$ & \\
\hline 11 & $\begin{array}{l}\text { Note on overthrow Gāzartā by amìr Badrū (in the } \\
\text { scribe's hand) }\end{array}$ & $114 \mathrm{r}$ & \\
\hline 12 & $\begin{array}{l}\text { Explanations of terms + quatrain on wisdom and } \\
\text { reading books (in the scribe's hand) }\end{array}$ & $114 \mathrm{~V}$ & $111 \mathrm{~V}$ \\
\hline 13 & $\begin{array}{l}\text { Poem about injustice of the world (in the scribe's } \\
\text { hand) }\end{array}$ & $115^{r}$ & $112 \mathrm{r}$ \\
\hline 14 & $\begin{array}{l}\text { Mēmrā about the soul that is like a bird, by Bar } \\
\text { Ma'danī (in the scribe's hand) }\end{array}$ & $115 \mathrm{~V}-121 \mathrm{~V}$ & $112 \mathrm{~V}-118 \mathrm{~V}$ \\
\hline 15 & $\begin{array}{l}\text { Mēmrā about nobility the soul and its humilia- } \\
\text { tion though breaking commandments, by the } \\
\text { same one (in the scribe's hand) }\end{array}$ & $121 \mathrm{~V}-122 \mathrm{~V}$ & $118 \mathrm{v}-12$ or \\
\hline 16 & $\begin{array}{l}\text { Mèmrā on the way of the perfect and their grades, } \\
\text { by the same one (in the scribe's hand) }\end{array}$ & $123^{r-129 r}$ & $120 \mathrm{or}-126 \mathrm{r}$ \\
\hline 17 & $\begin{array}{l}\text { Madrāša by priest Ṭalyā on late his brother (later } \\
\text { addition in a different hand) }\end{array}$ & $129 \mathrm{v}-13$ or & - \\
\hline 18 & $\begin{array}{l}\text { Mēmrā on divine wisdom, by a philosopher, i.e. } \\
\text { by Bar 'Ebrōyō (in the scribe's hand) }\end{array}$ & $130 v-138 v$ & - \\
\hline 19 & $\begin{array}{l}\text { On wisdom that can be obtained only through } \\
\text { journeys, by Khāmīs (in the scribe's hand) }\end{array}$ & $138 \mathrm{v}-139 \mathrm{r}$ & - \\
\hline 20 & $\begin{array}{l}\text { Nine quatrains by Maphrian, i.e. Bar 'Ebrōyō (in } \\
\text { the scribe's hand) }\end{array}$ & $140 \mathrm{ov}-141 \mathrm{r}$ & - \\
\hline 21 & $\begin{array}{l}\text { Short poems in Arabic and Garshuni (in the } \\
\text { scribe's hand) }\end{array}$ & $141 \mathrm{r}-142 \mathrm{r}$ & - \\
\hline 22 & $\begin{array}{l}\text { Nine quatrains in praise of pastors by Maphrian, } \\
\text { i.e. Bar 'Ebrōyō (in the scribe's hand) }\end{array}$ & $142 \mathrm{~V}-143 \mathrm{~V}$ & - \\
\hline 23 & $\begin{array}{l}\text { Five quatrains by priest Țalyā (later addition in a } \\
\text { different hand) + ownership notes in Syriac and } \\
\text { Arabic (in different hands) }\end{array}$ & $142 \mathrm{~V}-143 \mathrm{~V}$ & - \\
\hline 24 & $\begin{array}{l}\text { Two quatrains by Yawsep (later addition in a } \\
\text { different hand) }\end{array}$ & $145^{r}$ & - \\
\hline
\end{tabular}


TABLE 2 Contents of DCA 00065 and CCM 00024 containing Metrical Grammar (cont.)

\begin{tabular}{llll}
\hline $\begin{array}{l}\text { Number } \\
\text { of the text }\end{array}$ & The Text Title & $\begin{array}{l}\text { Foliation in } \\
\text { DCA ooo65 }\end{array}$ & $\begin{array}{l}\text { Foliation in } \\
\text { CCM ooo24 }\end{array}$ \\
\hline 25 & Short poems (in the scribe's hand) & $145 \mathrm{v}$ & - \\
26 & Notes and comments (in the scribe's hand) & $145^{\mathrm{r}-148 \mathrm{r}}$ & - \\
27 & Two quatrains (later addition in a different hand) & $148 \mathrm{v}$ & - \\
\end{tabular}

\section{$6 \quad$ Bilingual (Syriac and Arabic) Manuscript SMMJ 00159 Written by 'Abdīšóc of Gāzartā ${ }^{44}$}

This manuscript was written by 'Abdīšō' in 1566 while he was a patriarch (see Table 1, no. 6). As follows from the verse colophon (see Appendix 2), it was scribed for Mār Ya'qōb, the supervisor of the Ya'qōb Ḥbīšāyā monastery, the patriarchal residence. ${ }^{45}$ Like the versified colophon of SMMJ 00116, that of this manuscript has a strophic structure of 7-7-7-7 syllables in each stanza, with a regular rhyme. The manuscript contains a lot of varied texts, including Questions and answers by John Chrysostom (fol. 3v-46v); Syriac-Arabic and GreekSyriac vocabularies (fol. 46v-55v); Homily on fasting and on the Pentateuch by Ephrem of Nisibis (fol. 138v-139r). Besides, the copy contains numerous hymns and poems by 'Abdīšō' of Gāzartā himself, 'Abdīšō' of Ātēl (later addition), Abrāhām of Bēt Slōk, and Israel of Alqosh (later addition).

It is the only extant autograph by 'Abdī̌šc that contains considerable texts in Arabic written in his hand; thus that we can learn how his handwriting in this script looks like. Besides, it contains numerous poems in both Syriac and Arabic in the same hands and a lot of notes. The Arabic and bilingual poems deserve a special research, since they were never studied before. In cases where they are attributed to 'Abdīšo ' himself, he should be treated as a bilingual poet, which reflects on the general linguistic and social situation the Christian communities were facing in Islamic times.

44 See the description in Dolabani, Catalogue of the Syriac Manuscripts, pp. 339-344; Available online; vHMML permanent link: <https://w3id.org/vhmml/readingRoom/ view/501291>.

45 Scher, Catalogue des manuscrits syriaques et arabes, conservés dans la Bibliothèque épiscopale de Séert, pp. 11-12. 


\section{7}

\section{Conclusion}

By the mid-sixteenth century, the custom of copying manuscripts had become an important part of the activities of the Syriac Church hierarchs in preserving and transmitting the literary tradition, something which might have first appeared in the time of the Syriac Renaissance. They used to produce manuscripts not only for their own use, but also for the clerics subordinate to them, thus, supplying them with authorized texts. That is why the "text authority" became such an important part of the colophon at that time. Besides, it might be since the period of the Syriac Renaissance that the hierarchs got much involved in composing poetry. They generally follow poetic models created by the authors from the Syriac Renaissance, including shirt poems, especially quatrains. The latter obtained even greater popularity by the sixteenth century, when hierarchs, scribes and readers used to make additions and notes on various subjects. Thus, being an essential part of the literary and spiritual life of the Church, the manuscripts register its numerous different layers and aspects of the history of the Christian community in the Near East.

\section{Appendix 1}

[Verse colophon by 'Abdīšōo of Gāzartā, smmJ oo116 (St. Mark Monastery, Jerusalem 116), fol. 114v]

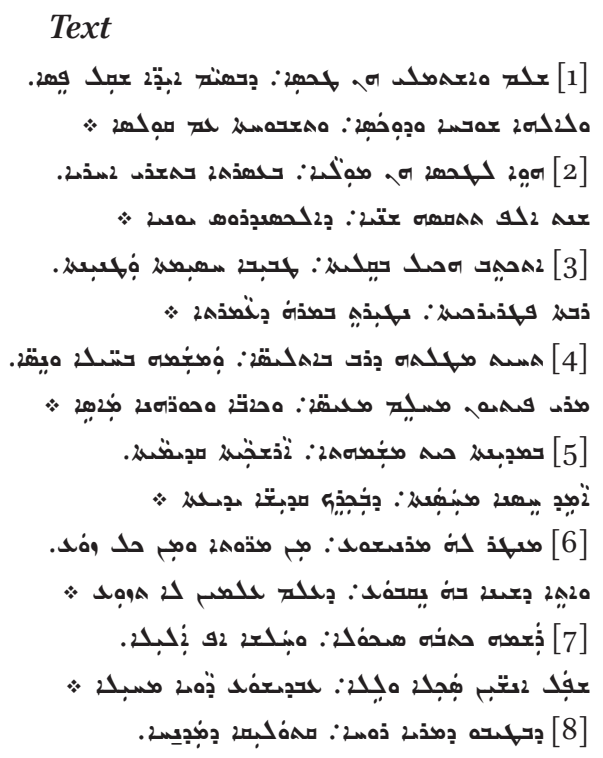




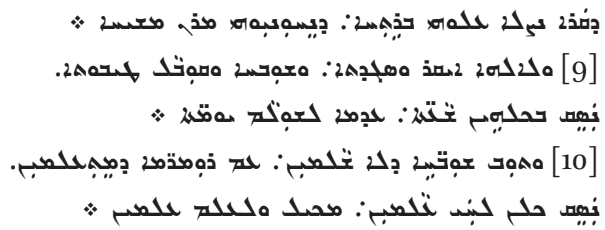

\section{Translation}

[1] This book of offices known as Rites of ordination is finished and completed.

So, glory and doxology to God, and also glorification and praise!

[2] The completion of this office took place on the tenth of the Last Teshri ${ }^{46}$ of year one thousand and 865 by Alexander the Greek. ${ }^{47}$ [3] Thus, it was written in the famous, excellent cell, the source of envy, the great Patriarchal one, guarded by the Lord of the inhabited earth, [4] under the protection of the great at battles and the supporter of the weak and feeble, Mār Pētiōn, the healer of the destroyed ones, the curer of illnesses and deceases,

[5] in the famous city, royal, ancient, Amid, the fortified fortress, known as city of saints.

[6] May our Lord Jesus guard it from disturbances and any revolts. May the sign of peace settle in it that will not be shaken forever and ever! [7] It was copied and written by the puny, limp and sickly, lowest of all people, foolish and fatuous, weak and feeble 'Abdǐšóc, [8] who is Catholicos of the East by the grace of the Lord Spirit.

May the reader pray for him with fervor,

$46 \quad$ Teshri II $=$ November

47 I.e. $1554 \mathrm{CE}$. 
so that our Lord Christ rescues him.

[9] Honor and veneration to God, also glory, and may He grant reception of Grace at all hours till the end of the days. [10] And so, let us all give endless praise with untiring exaltations to the Life of the worlds now and also forever and ever!

\section{Appendix 2}

[Verse colophon by 'Abdīšōo of Gāzartā, smMJ 00159 (St. Mark Monastery, Jerusalem 159), fol. 133r]

\section{Translation}

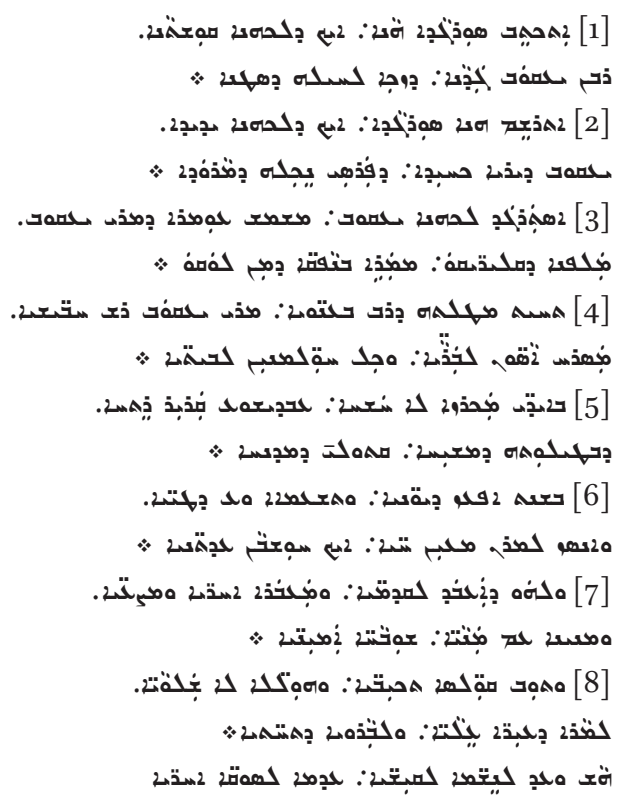

\section{Translation}

[1] This poem ${ }^{48}$ was written

for the true priest,

the lucky Rabban Ya'qōb,

48 Or: this line. 
who defeated the power of Satan.

[2] This poem was scribed

for the loved priest

Ya'qōb, the reverent monk,

who has revealed the guile of the rebellious one. ${ }^{49}$

[3] It was drawn for the priest Ya'qōb,

the steward of the monastery of Mār Ya'qōb,

the teacher of the clergymen,

imitator of the those leaving Egypt ${ }^{50}$

[4] under a canopy of the leader of the ascetics,

Mār Ya'qōb, head of the anchorites,

granting cure to the outsiders

and various healings to the insiders

[5] with the hands of an non-proper preacher

'Abdīšō', whose flame has got cold,

who is by the grace of Christ

Catholicos of the East,

[6] in year 1877 by the Greeks,

and 970 by the Arabs,

and 1567 by our Lord, the source of life,

according the Church reckoning.

[7] And to Him, who surpassed the ancient [times],

and surpasses the new and the middle ones,

numbering and numerals ,

be permanent glory.

[8] And also cheerful praises,

and uninterrupted chanting

to the Lord of the elevated guardians

and the Creator of those below,

now and as long as [one] respires,

and until the last breaths!

49 I.e. the demon.

$5^{0}$ (Lycos, Lycus) means the land Egypt; cf. R. Payne Smith, Thesaurus Syriacus, Oxford, 1879-1901, col. 1916. 